\title{
İzmir Yöresindeki Üreticilerin Mekanizasyon Düzeylerinin Belirlenmesi Üzerine Bir Araştırma
}

\author{
Mustafa Nazım MAVIOĞLU ${ }^{* 1}$ (D), Ferit ÇOBANOĞLU² \\ ${ }^{1}$ CIHEAM IAMZ Av.Montañana 1005 50059, Zaragoza, iSPANYA \\ ${ }^{2}$ Aydın Adnan Menderes Üniversitesi Ziraat Fakültesi Tarım Ekonomisi Bölümü, Güney Yerleşkesi, AYDıN
}

Öz: Üreticilerin traktör talebi, satın alma davranışları ve kullanım memnuniyetleri, piyasada karar vericiler açısından önemli ipuçları taşımaktadır. Gerçekleştirilen çalışma İzmir yöresinde ikamet eden üreticilerin sahip oldukları mekanizasyon düzeylerinin belirlenmesini amaçlamaktadır. Çalışmanın ana materyalini, İzmir ilinde, 170 adet çiftçi ile yapılan anket çalışmasından elde edilen veriler oluşturmuştur. Örnekleme yöntemi olarak Basit Tesadüfî Örnekleme Yöntemi kullanılmıs olup, örnek hacminin hesaplanmasında ise, Oransal Örnek Hacmi Hesaplama formülünden yararlanılmıştır. Illk olarak anket çalışmasından elde edilen veriler Excel bilgisayar programına girilmiştir. Daha sonra, SPSS istatistik paket programını kullanarak veriler için merkezi eğilim ölçüleri, diğer bir deyişle basit tanımlayıcı istatistikler (ortalama, minimum ve maksimum değerler, yüzde oranı vb.) kullanılarak analizler ve değerlendirmeler yapılmıştır. Bu çalışmanın sonucunda, yöre üreticilerinin \%60'ına yakınının sadece bir adet traktörünün bulunduğu belirlenmiştir. Üreticilerin yaklaşık olarak yarısının, traktör satın alırken 50 beygirin altında bir güç grubunu tercih etmekte olduğu görülmektedir. Bu da üreticilerin yakıt tüketimine büyük ölçüde önem verdiğini ortaya koymaktadır. Yöre genelinde traktör markalarının tercih nedenleri arasında yakıt, dayanıklıık, yedek parça temini ve yaygın kullanımının olduğu belirlenmiştir. Üreticilerin, traktör satın almalarındaki faktörler irdelendiğinde; temel faktör olarak deneyim (tarla tatbikatı), kişisel faktör olarak marka değeri, sosyal faktör olarak servis ağı, komşu/arkadaşlar ve baba/kayınpeder, teknik faktör olarak gücü ve dayanıklılığı, ekonomik faktör olarak yakıt tüketiminin olduğu görülmektedir.

Anahtar Kelimeler: traktör talebi, satın alma davranışları, traktör memnuniyeti, oransal örnek hacmi, yakıt tüketimi

\section{A Research on the Determination of Mechanism Levels of Farmers in İzmir City}

\begin{abstract}
Purchasing behaviors, usage satisfaction, and tractor demand of farmers have important clues for decision makers in markets. The aim of this study is to determine the mechanization levels of the producers residing in izmir region. Main material of the study is consisted of the primary data obtained from the survey studies performed with 170 enterprises/farmers in Izmir. While Simple Random Sampling is used as a sampling method, it is benefited from Proportional Sampling Formula during calculation of sampling size. Firstly data obtained from the survey studies is entered to Excel computer programmer. And then, analyses and evaluations are carried out using central tendency measures in other way descriptive statistics (mean, minimum and maximum values, percentage rate etc.) for the data by using SPSS statistic packet programmer. As a result; it is determined that only one tractor belongs to $60 \%$ of the farmers. It is seen that approximately half of the producers prefer a power group below 50 horsepower when buying a tractor. This shows that the producers attach great importance to fuel consumption. Among the reasons for the preference of tractor brands across the region, fuel, durability, spare parts supply and widespread use have been determined. When investigating the factors of the farmers intended for defining purchasing of the tractors, it can be seen that experience (field application) as major factor, brand value as personal factor, service network, neighbor/friends, and father/father-in-law as social factors, power and durableness as technical factors, fuel consumption as economic factor.
\end{abstract}

Keywords: Tractor demand, purchasing behaviors, tractor satisfaction, fuel consumption

\section{GíRiş}

Tarım, insanların geçimlerini sağlamak, gıda gereksinimlerini karşılamak amacıyla bitkisel ve hayvansal ürünlerin üretilmesi ve sonrasında çeşitli aşamalarda değerlendirilmesidir. Tarım sektörü, ülke ekonomisi açısından oldukça stratejik bir yere sahiptir. Sektör, zincirleme olarak sanayi ve hizmet sektörünün gelişimine katkı sağlamaktadır. İnsanlığın ilk çağlarından günümüze kadar gelen barınma, beslenme ve giyinme gibi temel ihtiyaçlar önemini korumuştur. Üretim olarak bakıldığında, bu ihtiyaçların nüfusa oranla artış göstermesi, sınırsız ihtiyaçların karşılanması için sınırlı kaynakların üretim sürecinde teknolojiyi zorunlu kılmıştır. Bu bağlamda üretim sürecinin kaliteli ve verimli olabilmesi için, bu sürecin ve aynı zamanda girdilerin kalitesi önemlidir. Bahse konu durumların eksik olması durumunda, yetiştirilecek ürünün verimi ve kalitesi de düşecektir. Tarımsal üretimin birim alandaki rekolte artışı ve yüksek verimli olmasında, üretim sürecinde bazı ihtiyaçlara gerek vardır. Bu ihtiyaçların en önemlisi mekanizasyon girdisidir. Tarımsal mekanizasyon; insan, hayvan, mekanik-elektrik vb. güç kaynakları ile uygun makineleri kullanarak bitkisel ve hayvansal üretim

Sorumlu Yazar: n.maviogluu@hotmail.com.tr Bu çalışma lisans tez ürünüdür.

Geliş Tarihi: 3 Eylül 2019

Kabul Tarihi: 27 Mayıs 2019 
faaliyetlerinin ve ürünlerin temel değerlendirme işlemlerinin mekanize edilmesidir. Mekanizasyon, hem üretimde, hem de insan gücü kullanımında, verimliliğin arttırılması ve böylece tarım alanlarının geliştirilmesini sağlamaktır (Evcim ve ark., 2005).

Teknolojiden yararlanma, teknolojinin gelişiminin yanı sıra üreticilerin bilinçlenmesiyle ortaya çıkan bir değerdir. Üreticilerin bilinçlenmesiyle birlikte çevrebilimle ilgili değerlere de önem verilmektedir. Daha az yakıt kullanmak, atmosfere daha az egzoz gazı salınımı, tarlada çalışırken kombine ekipman ve gelişmiş traktörleri kullanarak tarla trafiğini azaltmak ve toprak sıkışmasını en aza indirmek, zaman ve iş gücü gereksinimini azaltmak, girdi kullanımının azaltılması gibi konular bilinçli üreticilerin imkanları çerçevesinde dikkat ettikleri konular haline gelmiştir. Bu bağlamda ekonomik olması koşuluyla, yeniliklere talep artmaktadır. Talebin artması sektördeki firmaları Çizelge 1. Türkiye'de bulunan traktör sayısındaki gelişim (TÜiK, 2018) zorlayacak, teknolojiyle birlikte traktör sektörü de gelişecek ve yeniliklerin piyasaya girmesine neden olabilecektir.

Devam etmekte olan faiz indirimleri ve güçlü devlet destekleri sayesinde, Türkiye traktör ve diğer tarımsal makine pazarında talebin, halen oldukça önemli düzeyde iyi olduğu ifade edilebilir (Çobanoğlu ve ark., 2016; Anonim, 2017). Türkiye'de mekanizasyon kullanımına ilişkin olarak en önemli göstergeler olan, tarımda kullanılan traktör sayısı (Çizelge 1) ve İzmir ilinde bulunan traktör sayısının (Çizelge 2) yanı sıra, son beş yıl için Türkiye geneli (Çizelge 3) ve araştırma yöresi olan İzmir ilindeki mevcut olan tarımsal alet ve makine sayısı (Çizelge 4), yıllara göre önemli sayılabilecek düzeyde artış göstermiştir. Gerçekleştirilen bu çalışma İzmir yöresindeki üreticilerin sahip oldukları mekanizasyon düzelerini belirlemeyi amaçlamaktadır. Gerçekleştirilen çalışmanın ilgili sektöre katkı sağlayacağı düşünülmektedir.

\begin{tabular}{|c|c|c|c|c|c|c|c|c|c|c|c|}
\hline \multirow[t]{2}{*}{ Yillar } & \multirow[t]{2}{*}{ Toplam } & \multicolumn{2}{|c|}{$\begin{array}{l}\text { Tek akslı } \\
\text { Beygir Gücü }\end{array}$} & \multicolumn{7}{|c|}{$\begin{array}{l}\text { İki akslı } \\
\text { Beygir gücü }\end{array}$} & \multirow[t]{2}{*}{ Tirtıllı } \\
\hline & & $1-5$ & $5+$ & $1-10$ & $11-24$ & $25-34$ & $35-50$ & $50+$ & $51-70$ & $70+$ & \\
\hline 1988 & 654,636 & 623 & 1,311 & 2,655 & 16,741 & 62,230 & 351,210 & 219,545 & - & - & 321 \\
\hline 1990 & 692,454 & 1,234 & 1,570 & 3,175 & 17,841 & 66,696 & 364,052 & 237,579 & - & - & 307 \\
\hline 1995 & 776,863 & 1,022 & 3,445 & 2,841 & 19,960 & 72,535 & 389,023 & 287,616 & - & - & 421 \\
\hline 2000 & 941,835 & 2,049 & 7,882 & 3,776 & 20,409 & 77,364 & 446,541 & 383,424 & - & - & 390 \\
\hline 2005 & $1,022,365$ & 2,848 & 13,321 & 3,495 & 20,264 & 77,205 & 460,336 & - & 382,448 & 62,237 & 211 \\
\hline 2010 & $1,096,683$ & 5,235 & 20,176 & 5,344 & 19,997 & 72,411 & 471,531 & - & 414,977 & 86,813 & 199 \\
\hline 2015 & $1,260,358$ & 14,856 & 54,604 & 6,252 & 21,181 & 68,074 & 491,828 & - & 468,060 & 135,297 & 206 \\
\hline 2016 & $1,273,531$ & 15,736 & 57,131 & 6,448 & 21,274 & 66,825 & 489,621 & - & 475,665 & 140,699 & 132 \\
\hline 2017 & $1,306,736$ & 16,589 & 59,061 & 6,432 & 20,527 & 65,866 & 492,343 & - & 493,660 & 152,133 & 125 \\
\hline
\end{tabular}

Çizelge 2. izmir ilinde bulunan traktör sayısındaki gelişim (TÜiK, 2018)

\begin{tabular}{lllllllllll}
\multirow{2}{*}{ Yıllar } & \multirow{2}{*}{ Toplam } & \multicolumn{2}{l}{ Tek akslı } \\
Beygir Gücü & \multicolumn{2}{l}{$\begin{array}{l}\text { Iki akslı } \\
\text { Beygir gücü }\end{array}$} \\
\cline { 3 - 12 } & & $1-5$ & $5+$ & $1-10$ & $11-24$ & $25-34$ & $35-50$ & $51-70$ & $70+$ & \multirow{2}{*}{ Turtıllı } \\
\hline 2004 & 30,888 & 18 & 40 & 500 & 1,206 & 3,214 & 16,728 & 8,622 & 554 & 6 \\
2005 & 31,112 & 18 & 39 & 193 & 869 & 3,173 & 17,049 & 9,218 & 547 & 6 \\
2010 & 32,567 & 15 & 81 & 191 & 809 & 3,138 & 17,447 & 9,779 & 1,105 & 2 \\
2015 & 34,287 & 28 & 219 & 209 & 832 & 3,115 & 17,398 & 11,011 & 1,473 & 2 \\
2016 & 34,424 & 28 & 221 & 201 & 822 & 3,109 & 17,200 & 11,334 & 1,507 & 2 \\
2017 & 34,818 & 28 & 230 & 202 & 863 & 3,241 & 17,228 & 11,473 & 1,552 & 1 \\
\hline
\end{tabular}

Traktör talebindeki çiftçilerin davranışları, süregelen üretimin yapıldığı arazi miktarı ve koşullarına bağlıdır. Üretimi gerçekleştiren çiftçi, kendi mevcut kaynaklarına göre traktör talep etmelidir. Aksi durumda, önemli girdi kayıplarına ve ekolojik kirliliğe neden olabilme potansiyeli mevcuttur. Genel anlamda kaynaklara uyumlu optimum mekanizasyon girdisi ile üretilen standart ürünlerin, tüketiciler açısından talep göreceği ve büyük alanda üretim yapan çiftçilerin, iç piyasa fazlasını, uygun koşullarda depolama sonrası ihracatıyla ülke ekonomisine katkı 20 sağlayacağı kaçınılmazdır. Gerçekleştirilen çalışma İzmir yöresinde ikamet eden üreticilerin sahip oldukları mekanizasyon düzeylerinin belirlenmesini amaçlamaktadır.

\section{MATERYAL VE YÖNTEM}

Çalışmanın ana materyalini, diğer bir ifade ile birincil veri kaynağını, İzmir il'i Ödemiş, Tire, Torbalı, Kiraz, Bayındır ve Beydağ ilçelerinde ikamet eden 170 adet çiftçi ile yüz yüze yapılan anket çalışmasından elde edilen veriler oluşturmuştur. Ayrıca, ikincil veri kaynağı olarak, konu ile ilgili olarak daha önce yapılmış olan araştırma 
Çizelge 3. Türkiye'deki bazı tarımsal alet ve makine sayısındaki gelişim (TüiK, 2018)

\begin{tabular}{|c|c|c|c|c|c|}
\hline Tarımsal alet ve makineler & 2013 & 2014 & 2015 & 2016 & 2017 \\
\hline Ark açma pulluğu & 66,791 & 66,150 & 66,879 & 68,117 & 68,654 \\
\hline Atomizör & 116,789 & 115,995 & 116,883 & 120,402 & 121,448 \\
\hline Biçerdöver & 15,486 & 15,899 & 15,998 & 16,247 & 17,199 \\
\hline Damla sulama tesisi & 318,413 & 362,033 & 389,831 & 412,468 & 441,366 \\
\hline Derin kuyu pompa & 148,675 & 163,275 & 168,502 & 172,923 & 179,659 \\
\hline Dipkazan (Subsoiler) & 30,401 & 32,568 & 35,132 & 36,515 & 38,127 \\
\hline Diskli anız pulluğu & 44,387 & 45,405 & 45,002 & 45,365 & 46,540 \\
\hline Diskli tırmık (Diskarolar) & 232,278 & 235,594 & 240,303 & 243,310 & 247,121 \\
\hline Diskli traktör pulluğu & 68,773 & 70,701 & 71,829 & 72,448 & 73,139 \\
\hline Elektropomp & 192,378 & 203,614 & 210,045 & 214,407 & 221,016 \\
\hline Fide dikim makinesi & 13,894 & 14,145 & 14,188 & 13,939 & 13,820 \\
\hline Hayvan pulluğu & 110,903 & 89,155 & 82,732 & 78,344 & 70,471 \\
\hline Hayvanla ve traktörle çekilen ara çapa makinesi & 133,608 & 132,603 & 135,684 & 136,942 & 139,385 \\
\hline Karasaban & 45,965 & 40,695 & 37,455 & 34,643 & 31,330 \\
\hline Kimyevi gübre dağıt. Mak. & 389,918 & 392,908 & 399,451 & 408,737 & 419,388 \\
\hline Kombikürüm & 24,495 & 23,555 & 23,881 & 24,352 & 24,786 \\
\hline Kombine hububat ekim makinesi & 202,915 & 205,286 & 208,403 & 211,348 & 217,642 \\
\hline Krema makinesi & 197,520 & 182,920 & 178,535 & 177,268 & 174,176 \\
\hline Kulaklı traktör pulluğu & $1,045,122$ & $1,046,048$ & $1,050,237$ & $1,057,870$ & $1,071,553$ \\
\hline Kuyruk milinden haraketli pülverizatör & 312,651 & 322,174 & 329,768 & 338,625 & 350,272 \\
\hline Kültüvatör & 503,786 & 508,218 & 515,172 & 520,970 & 532,508 \\
\hline Merdane & 83,487 & 84,819 & 86,138 & 87,374 & 91,011 \\
\hline Motopomp (Termik) & 194,154 & 191,855 & 192,827 & 192,871 & 192,841 \\
\hline Motorlu pülverizatör & 80,457 & 84,093 & 85,974 & 87,486 & 90,832 \\
\hline Orak makinesi & 61,954 & 60,645 & 58,271 & 57,234 & 53,972 \\
\hline Ot tırmı ̆̆ & 106,668 & 110,030 & 113,405 & 115,169 & 115,809 \\
\hline Patates dikim makinesi & 15,152 & 15,421 & 15,769 & 16,087 & 16,717 \\
\hline Patates sökme makinesi & 19,756 & 20,229 & 20,462 & 20,353 & 21,250 \\
\hline Pnömatik ekim makinesi & 30,921 & 32,048 & 34,589 & 35,850 & 39,024 \\
\hline Römork (Tarım arabası) & $1,109,917$ & $1,121,371$ & $1,126,166$ & $1,137,709$ & $1,165,873$ \\
\hline Santrifüj pompa & 108,872 & 111,593 & 111,682 & 113,075 & 114,159 \\
\hline Sap döver ve harman makinesi (Batöz) & 181,320 & 173,555 & 170,836 & 167,581 & 160,121 \\
\hline Sap parçalama makinesi & 17,889 & 17,864 & 18,239 & 18,533 & 19,014 \\
\hline Sedyeli, motorlu pulverizatör tozlayıcı kombine atomizör & 14,325 & 13,811 & 12,731 & 12,802 & 13,832 \\
\hline Set yapma makinesi & 16,004 & 15,796 & 16,131 & 16,639 & 16,650 \\
\hline Sırt pülverizatörü & 612,626 & 623,190 & 628,059 & 633,598 & 641,819 \\
\hline Su tankeri (Tarımda kullanılan) & 208,544 & 208,538 & 209,372 & 210,697 & 213,393 \\
\hline Süt sağım makinesi (Seyyar) & 268,164 & 282,433 & 292,405 & 301,795 & 319,885 \\
\hline Tınaz makinesi & 10,710 & 8,405 & 8,111 & 7,739 & 7,440 \\
\hline Toprak tesviye makinesi & 17,657 & 17,919 & 18,238 & 18,873 & 19,182 \\
\hline Tozlayıcı & 19,307 & 17,827 & 17,855 & 17,749 & 16,762 \\
\hline Traktör & $1,213,560$ & $1,243,300$ & $1,260,358$ & $1,273,531$ & $1,306,736$ \\
\hline Traktörle çekilen çayır biçme makinesi & 73,314 & 79,115 & 81,480 & 82,899 & 87,233 \\
\hline Traktörle çekilen hububat ekim makinesi & 131,471 & 134,786 & 136,846 & 140,329 & 142,258 \\
\hline Üniversal ekim makinesi (Mekanik) (Pancar mibzeri dahil) & 61,922 & 61,337 & 61,353 & 61,018 & 61,660 \\
\hline Yağmurlama tesisi & 240,253 & 247,520 & 248,039 & 252,215 & 259,838 \\
\hline Yayık & 252,104 & 248,815 & 248,720 & 249,297 & 256,123 \\
\hline Yem hazırlama makinesi & 25,891 & 26,924 & 27,747 & 28,979 & 31,962 \\
\hline
\end{tabular}


Çizelge 4. İzmir ilindeki bazı önemli tarımsal alet ve makine sayısındaki gelişim (TÜiK, 2018)

\begin{tabular}{|c|c|c|c|c|c|}
\hline Tarımsal alet ve makineler & 2013 & 2014 & 2015 & 2016 & 2017 \\
\hline Hayvan pulluğu & 3,775 & 2,976 & 2,515 & 1,977 & 1,443 \\
\hline Kulaklı traktör pulluğu & 31,731 & 32,010 & 32,056 & 31,979 & 31,911 \\
\hline Ark açma pulluğu & 8,232 & 8,466 & 8,867 & 8,992 & 9,112 \\
\hline Diskli traktör pulluğu & 1,534 & 1,528 & 1,523 & 1,521 & 1,566 \\
\hline Toprak frezesi (rotovatör) & 3,464 & 3,528 & 3,569 & 3,588 & 3,732 \\
\hline Kültivatör & 11,400 & 11,852 & 12,166 & 12,172 & 12,354 \\
\hline Merdane & 1,655 & 1,699 & 1,753 & 1,721 & 1,743 \\
\hline Diskli tırmık (diskarolar) & 15,128 & 15,300 & 15,460 & 15,440 & 15,722 \\
\hline Dişli tırmık & 18,548 & 18,615 & 18,706 & 18,703 & 18,775 \\
\hline Kombikürüm (karma tırmık) & 1,696 & 1,677 & 1,654 & 1,656 & 1,639 \\
\hline Ot tırmığı & 1,503 & 1,508 & 1,536 & 1,537 & 1,543 \\
\hline Patates dikim makinesi & 2,292 & 2,337 & 2,336 & 2,347 & 2,864 \\
\hline Kimyevi gübre dağıtma makinesi & 13,737 & 15,091 & 15,267 & 15,346 & 15,767 \\
\hline Patates sökme makinesi & 2,407 & 2,599 & 2,599 & 2,599 & 2,865 \\
\hline Mısır silaj makinesi & 2,889 & 3,251 & 3,331 & 3,399 & 3,801 \\
\hline Sap parçalama makinesi & 1,679 & 1,724 & 1,711 & 1,708 & 1,596 \\
\hline Sırt pülverizatörü & 34,267 & 34,484 & 34,542 & 34,691 & 35,940 \\
\hline Kuyruk milinden hareketli pülverizatör & 10,079 & 10,168 & 10,250 & 10,304 & 10,540 \\
\hline Motorlu pülverizatör & 5,041 & 5,135 & 4,545 & 4,645 & 4,838 \\
\hline Atomizör & 8,954 & 8,999 & 9,037 & 9,051 & 9,119 \\
\hline Santrifüj pompa & 4,370 & 4,192 & 4,222 & 4,228 & 4,267 \\
\hline Elektropomp & 23,432 & 18,351 & 18,663 & 18,724 & 18,918 \\
\hline Motopomp (termik) & 6,776 & 6,662 & 6,165 & 6,176 & 6,003 \\
\hline Derin kuyu pompa & 16,474 & 27,866 & 28,254 & 28,425 & 28,597 \\
\hline Süt sağım makinesi (seyyar) & 11,433 & 12,246 & 12,382 & 12,767 & 13,128 \\
\hline Römork (tarım arabası) & 31,245 & 32,064 & 32,028 & 32,219 & 32,409 \\
\hline Su tankeri (tarımda kullanılan) & 10,276 & 10,372 & 10,437 & 10,449 & 10,515 \\
\hline Toprak tesviye makinesi & 1,204 & 1,237 & 1,242 & 1,246 & 1,261 \\
\hline Set yapma makinesi & 2,027 & 2,022 & 2,018 & 2,041 & 1,885 \\
\hline Hayvanla ve traktörle çekilen ara çapa makinesi & 14,382 & 13,703 & 13,718 & 13,659 & 13,503 \\
\hline Üniversal ekim makinesi (mekanik) (pancar mibzeri dahil) & 13,928 & 13,863 & 13,803 & 13,804 & 13,768 \\
\hline Damla sulama tesisi & 14,929 & 15,595 & 16,384 & 16,803 & 17,173 \\
\hline
\end{tabular}

sonuçlarından, raporlardan ve internet adreslerinden yararlanılmıştır. Örnekleme yöntemi olarak Basit Tesadüfi Örnekleme Yöntemi kullanılmıştır. 170 adet olan örnek hacminin hesaplanmasında ise, Oransal Örnek Hacmi Hesaplama formülünden yararlanılmıştır. Gerçekleştirilen analizlerde güven aralığı \%95 ve hata payı \%5 alınmıştır. Öncelikle, anket çalışmasından elde edilen veriler, Excel bilgisayar programına girilmiştir. Daha sonra, SPSS istatistik paket programı kullanılarak veri setine ait merkezi eğilim ölçüleri, diğer bir ifade ile basit tanımlayıcı istatistikler (aritmetik ortalama, minimum ve maksimum değerler, yüzde oranları vb.) kullanılarak, çeşitli analizler ve değerlendirmeler yapılmış, özet ve çapraz tablolar oluşturulmuştur.

\section{BULGULAR}

Araştırma yöresindeki çiftçilerin sosyo-demografik özellikleri

$\mathrm{Bu}$ bölümde araştırma yöresindeki çiftçilerin sosyodemografik özellikleri alt başlıklarda incelenmiştir (Çizelge 5).
Çiftçilerin deneyim, yaş, eğitim gibi bazı özellikleri Araştırma yöresindeki çiftçilerin, çiftçilik tecrübesi ortalaması $21.9 \mathrm{yıl}$, ailedeki kişi sayısı ortalaması 3, araştırma yöresinde tamamı erkek olan çiftçilerin yaşı ortalaması 41.6, çiftçilerin eğitim durumu ortalaması 7.7, çiftçilerin mevcut işletmelerindeki çalıştıkları gün sayısının ortalamasının ise 299.6 gün olduğu belirlenmiştir.

Araştırma yöresindeki çiftçilerin yaş grupları

Araştırma yöresindeki çiftçilerin yaş gruplarına göre; çiftçi sayıları, yüzdelik dilimleri ve birikimli yüzdelik dilimleri Çizelge 6'da sunulmuştur.

Araştırma yöresindeki çiftçilerin yaklaşık \%58'i 45 yaşın altındadır. 46-55 yaşları arasında bir yığılma görülmektedir. 56 yaş ve üzeri olanlar ise \%15.88'dir.

\section{Çiftçilerin eğitim bilgileri}

Eğitim süreleri açısından çiftçiler, ilkokul, ortaokul, lise ve yüksekokul mezuniyetlerine göre sınıflandırılmıştır (Çizelge 7). 
Çizelge 5. Araştırma yöresindeki çiftçilerin özellikleri

\begin{tabular}{llllll}
\hline Çiftçi Özellikleri & Minimum & Maksimum & Ortalama & Standart Sapma & Medyan \\
\hline Çiftçilik Tecrübesi (yıl) & 2 & 50 & 21.9 & 12.3 & 20 \\
Ailedeki Kiş̧ Sayısı (adet) & 1 & 7 & 3 & 1.4 & 3 \\
Yaş (yıl) & 15 & 69 & 41.6 & 13.6 & 42 \\
Eğitim (yıl) & 5 & 18 & 7.7 & 3.3 & 5 \\
İşletmede Çalıştığı Gün & 100 & 365 & 299.6 & 86.7 & 365 \\
\hline
\end{tabular}

Çizelge 6. Araştırma yöresinde çiftçilerin yaş gruplarına göre dağılımı

\begin{tabular}{llll}
\hline Yaş Grupları (Yıl) & Çiftçi Sayısı & \% & Birikimli\% \\
\hline$\leq 35$ & 61 & 35.88 & 35.88 \\
$36-45$ & 39 & 22.94 & 58.82 \\
$46-55$ & 43 & 25.29 & 84.11 \\
$\geq 56$ & 27 & 15.88 & 100 \\
Toplam & 170 & $\% 100$ & \\
\hline
\end{tabular}

\%27.05, 241 gün ve üzerinde çalışanların oranı ise \%70 oranında olduğu belirlenmiştir. 240 gün ve daha az çalışanların oranının ise $\% 30$ olduğu belirlenmiştir (Çizelge 9).

Çizelge 9. Çiftçilerin yıllık çalışma sürelerine göre dağılımı

\begin{tabular}{llll}
\hline Çalışılan Gün & Çiftçi Sayısı & $\%$ & Birikimli\% \\
\hline$\leq 120$ & 5 & 2.95 & 2.95 \\
$121-240$ & 46 & 27.05 & 30 \\
$\geq 241$ & 119 & 70 & 100 \\
Toplam & 170 & $\% 100$ & \\
\hline
\end{tabular}

Çizelge 7. Çiftçilerin eğitim guruplarına göre dağılımı

\begin{tabular}{llll}
\hline Eğitim Süresi (Yıl) & Çiftçi Sayısı & \% & Birikimli\% \\
\hline 5 & 90 & 52.94 & 52.94 \\
8 & 28 & 16.47 & 69.41 \\
$9-12$ & 37 & 21.76 & 91.17 \\
$\leq 13$ & 15 & 8.82 & 100 \\
Toplam & 170 & $\% 100$ & \\
\hline
\end{tabular}

Çiftçilerin yarıdan fazlası (\%52.94) ilkokul mezunu, \%16'sı ortaokul mezunu, $\% 21.76$ 'sı lise mezunu iken yüksek öğretim mezunu olanların oranı \%8.82 olarak tespit edilmiştir (Çizelge 7).

Çiftçilerin tecrübesi

Tarımsal üretimde deneyim önemli bir unsurdur. 10'ar yıllık deneyim sürelerine göre çiftçi sayıları ve oranları Çizelge 8'de verilmiştir.

Çizelge 8. Çiftçilerin deneyim gruplarına göre dağılımı

\begin{tabular}{|c|c|c|c|c|}
\hline $\begin{array}{l}\text { Çiftçilik } \\
\text { (Yıl) }\end{array}$ & Deneyimi & Çiftçi Sayısı & $\%$ & $\begin{array}{l}\text { Birikimli } \\
\%\end{array}$ \\
\hline$\leq 10$ & & 46 & 27.05 & 27.05 \\
\hline $11-20$ & & 42 & 24.70 & 51.75 \\
\hline $21-30$ & & 46 & 27.05 & 78.80 \\
\hline $31-40$ & & 28 & 16.47 & 95.27 \\
\hline$\geq 41$ & & 8 & 4.70 & 100 \\
\hline Toplam & & 170 & $\% 100$ & \\
\hline
\end{tabular}

10 ve daha az yıl deneyime sahip grup ile 21-30 yılları arası deneyime sahip grup \%27 ile ilk sırayı alırken, bu grubu sırasıyla 11-20 yıl, 31-40 yıl, ardından 41 ve üzeri yıl grubu izlemektedir. Çiftçilik deneyimi açısından, 31-40 yıl ve 41 yıl üzeri gruplarda, çiftçi sayısının en az olduğu tespit edilmiştir (Çizelge 8).

Çiftçilerin yıllık çalışma süreleri

Araştırma yöresinde faal olarak üretim yapan çiftçilerin yıl içerisinde çalıştığı gün durumlarına göre; çiftçi sayıları, yüzdelik dilimleri ve birikimli yüzdelik dilimleri Çizelge $9^{\prime} \mathrm{da}$ sunulmuştur.

$\mathrm{Bu}$ bölümde bir yıl içerisinde tarımsal amaçla çalışılan gün sayısı bulunmaktadır. Değerlendirme kolaylığı açısından çalışılan gün sayısı, dörder aylık üç döneme ayrılmıştır. Bir yıl içerisinde toplam çalışma günü 120 gün ve altında olanların oranı \%2.95, 121-240 gün arası çalışanların oranı

Çiftçilerin yaş gruplarına göre ortalama alan, traktör ve çalışılan gün bilgileri

Yöre üreticisinin yaş gruplarına denk düşen; ortalama alan miktarı (da), ortalama traktör sayısı (adet) ve ortalama çalışılan gün sayısı (gün) Çizelge 10 'da sunulmuştur.

Çizelge 10. Yaş gruplarına göre çiftçilerin sahip oldukları arazi büyüklüğü, traktör sayısı ve çalışılan gün sayısına göre dağılımı

\begin{tabular}{lllll}
\hline $\begin{array}{l}\text { Yaş } \\
\text { Grup. }\end{array}$ & Alan (da) & $\begin{array}{l}\text { Traktör } \\
\text { (adet) }\end{array}$ & Sayısı & $\begin{array}{l}\text { Çalışılan } \\
\text { Gün Sayısı }\end{array}$ \\
\hline$\leq 35$ & 46.95 & 1.72 & 273.93 \\
$36-45$ & 61.29 & 1.61 & 325.25 \\
$46-55$ & 48.55 & 1.09 & 315.46 \\
$\geq 56$ & 62.11 & 1.11 & 295.18 \\
\hline
\end{tabular}

Araştırma yöresindeki çiftçilerin yaş gruplarına göre ortalama alanları (da), ortalama traktör sayıları (adet) ve ortalama çalışılan gün sayıları (365 gün üzerinden) verilmiştir (Çizelge 10). Görüldüğü üzere en çok 56 yaş ve üstü çiftçilerin kişi başına düşen arazi miktarı 62 dekar civarında olup, en az 35 yaş ve altı çiftçilerin kişi başına düşen arazi miktarının 47 dekar civarında olduğu belirlenmiştir. Örneklem grubunda 35 yaş ve altı çiftçilerin kişi başına düşen traktör sayısı bakımından en fazla olduğu görülmektedir, bu duruma sebep olarak son yıllarda yörede yaşayan gençlerin çiftçiliğe/üretime yöneldikleri başka bir deyişle var olan mevcut üretimlerini arttırmak istedikleri sonucu çıkarılabilir. 56 yaş ve üstü çiftçilerin ise kişi başına düşen traktör sayısı bakımından en az olduğu belirlenmiştir. Araştırma bölgesinde yıllık ortalama çalışılan gün olarak bakıldığında, 36-45 yaş grubunun diğer gruplara kıyasla gün fazlası çalıştığı tespit edilmiştir.

Araştırma yöresindeki işletmelerin mekanizasyon varlığı

Araştırma yöresinde mekanizasyon durumu ayrıntılı olarak incelenmiştir.

\section{Traktör ve traktör gücü varlığı}

Araştırma anketine katılan 170 tarımsal işletmenin 153 'ünde en az 1 traktör olduğu, geri kalan 17 çiftçinin ise traktörünün olmadığı belirlenmiştir. Traktöre sahip işletmelerin traktör sayıları toplamı 247'dir (Çizelge 11). 
Çizelge 11. Araştırma yöresindeki işletmelerin traktör ve traktör gücü varlığı

\begin{tabular}{lllll}
\hline Mekanizasyon Düzeyi & Toplam & Minimum & Maksimum & Ortalama \\
\hline Traktör Sayısı & 247 & 0 & 7 & 1.45 \\
Traktör Gücü Varlığı (BG) & 14.760 & 0 & 135 & 86.82 \\
\hline
\end{tabular}

Toplam traktör gücü varlığının, beygir gücü cinsinden toplam 14.760 BG ve işletme başına ortalama traktör gücünün 86 BG olduğu hesaplanmıştır.

Araştırma yöresindeki işletmelerin traktör sayılarına göre dağılımı

Araştırma yöresindeki işletmelerin traktör sayılarına göre dağılımları Çizelge 12'de verilmiştir.

Çizelge 12. Araştırma yöresindeki işletmelerin traktör sayılarına göre dağılımı

\begin{tabular}{llll}
\hline Traktör Sayısı & İşletme Sayısı & \% & Birikimli\% \\
\hline 0 & 17 & 10.00 & 10.00 \\
1 & 97 & 57.06 & 67.06 \\
2 & 30 & 17.64 & 84.70 \\
3 & 19 & 11.17 & 95.87 \\
4 & 5 & 2.94 & 98.81 \\
6 & 1 & 0.59 & 99.40 \\
7 & 1 & 0.59 & 100.00 \\
Toplam & 170 & $\% 100$ & \\
\hline
\end{tabular}

Tarımsal işletmelerin \%10'unun traktörü yok iken, \%90'ının bir veya daha fazla traktörü bulunmaktadır. Bu işletmelerin yaklaşık \%57'sinin 1 adet, \%17'sinin 2 adet, \%11'inin 3 adet, \%3'ünün 4 adet, \%0,60'ının 6 ve \%0,60'ının 7 adet traktörü bulunmaktadır.

Araştırma yöresindeki işletmelerin sahip oldukları traktör güçlerinin gruplara göre dağılımı

Araştırma yöresindeki tarımsal işletmelerin sahip oldukları traktör güçleri aşağıda gruplandırılmıştır (Çizelge 13).

Çizelge 13. Araştırma yöresindeki işletmelerin sahip oldukları traktör güçlerinin gruplara göre dağılımı (BG)

\begin{tabular}{llll}
\hline $\begin{array}{l}\text { Traktör Gücü } \\
\text { Varlığı (BG) }\end{array}$ & İşletme Sayısı & $\%$ & Birikimli\% \\
\hline $\begin{array}{l}\text { Traktörü } \\
\text { Olmayan }\end{array}$ & 17 & 10.00 & 10.00 \\
$1-49$ & 77 & 45.29 & 55.29 \\
$50-69$ & 43 & 25.30 & 80.59 \\
$70-99$ & 29 & 17.05 & 97.64 \\
$\geq 100$ & 4 & 2.35 & 100.00 \\
Toplam & 170 & $\% 100$ & \\
\hline
\end{tabular}

Tarımsal İşletmelerin \%45'i 1-49 BG arasında traktör gücüne sahipken, \%25'i 50-69 BG arasında traktör gücüne sahiptir. Yaklaşık \%4'ü 100 BG ve üzerinde traktör gücü varlığına sahiptir.

Araştırma yöresindeki traktörlerin markalara göre dağılımı Araştırma yöresindeki traktörlerin markalara göre dağılımı Çizelge 14 'de verilmiştir. Traktörlerin yaklaşık yarısı (\%47) Massey Ferguson markalı traktörler oluştururken, \%19'u Fiat, \%13'ü New Holland ve geri kalanı ise diğer markalardan oluşmaktadır.

Araştırma yöresindeki işletmelerin mevcut ekipman varlığı Araştırma Yöresindeki ekipman durumu incelendiğinde çiftçilerin tarımsal faaliyetlerde kullandıkları ekipmanlar

\begin{tabular}{lll}
$\begin{array}{l}\text { Çizelge 14. Araştırma } \\
\text { göre dağılımı }\end{array}$ & \multicolumn{2}{l}{ yöresindeki traktörlerin markalara } \\
\hline Marka & Traktör Sayısı & $\%$ \\
\hline Massey Ferguson & 117 & 47.37 \\
Fiat & 49 & 19.84 \\
New Holland & 32 & 12.95 \\
John Deere & 11 & 4.45 \\
Case & 10 & 4.05 \\
Başak & 7 & 2.84 \\
Valtra & 6 & 2.43 \\
Erkunt & 5 & 2.03 \\
Hat-Tat & 2 & 0.81 \\
Kubota & 2 & 0.81 \\
Ls & 2 & 0.81 \\
Tümosan & 2 & 0.81 \\
Mc Cornıng & 1 & 0.40 \\
Universal & 1 & 0.40 \\
Toplam & 247 & $\% 100$ \\
\hline
\end{tabular}

sırası ile; römork, pulluk, diskaro, araçapa makinesi, pülverizatör, gübre dağıtma makinesi, tırmık, pünomatik mibzer, kültüvatör, slaj makinesi, biçme makinesi, tesviye makinesi, freze, dip kazan, set yapma makinesi, döner kulaklı pulluk, rotatiller, merdane, balya makinesi, mekanik mibzer ve fide dikim makinesi kullandıkları tespit edilmiştir (Çizelge 15).

Yöre genelini değerlendirebilecek bir kriter olan bu değer incelenecek olursa; araştırma yöresinde işletme başına 0.81 römork, 0.67 pulluk ve 0.51 diskaro ilk üç sırayı almaktadır. İşletme başına en düşük değere sahip ekipmanlar balya makinesi, mibzer ( $\mathrm{mk}$ ) ve fide dikim makinesidir.

\section{Araştırma yöresinin mekanizasyon durumu}

Araştırma yöresinin mekanizasyon düzeyi, 1,000 ha başına düşen traktör sayısına göre yapılmıştır (Çizelge 16).

Yörede araştırmaya katılan üreticilerin 1,000 ha işlenen alana düşen traktör sayısı ortalama 273.83 olarak belirlenmiştir. Karşılaştırma yapılabilmesi açısından İzmir yöresi ve Türkiye geneli değerleri de hesaplanmıştır. İzmir yöresi için 1,000 ha işlenen alana düşen traktör sayısı 107,39 iken, Türkiye için traktör sayısı 35.22 olarak hesaplanmıştır (Çizelge 16). Görüldüğü üzere, araştırma yöresinin değeri Türkiye genelinin yaklaşık sekiz katıdır. Tarımın İzmir ilı'indeki ağırlığı ve yöredeki tarımın oldukça yaygın olarak yapılıyor olması bu değerin yüksekliğinin nedenlerindendir.

İşlenen alan başına düşen traktör gücü düzeyi

Araştırma yöresindeki veriler ile birim alana düşen traktör gücü değeri hesaplanmıştır. Bu değer beygirgücü (BG) cinsinden sunulmuştur.

Yörede araştırmaya katılan üreticilerin mekanizasyon durumu 16.36 BG/ha olarak hesaplanmıştır (Çizelge 17). Bu değer, İzmir yöresi için 5.13 iken Türkiye geneli için 1.85 
Çizelge 15. Incelenen işletmelerin sahip oldukları toplam ve işletme başına düşen ekipman sayıları

\begin{tabular}{|c|c|c|c|}
\hline Ekipman & \multicolumn{2}{|c|}{ Toplam Ekipman Sayısı } & İşletme Başına Ekipman Sayısı \\
\hline Römork & \multicolumn{2}{|l|}{138} & 0.81 \\
\hline Pulluk & \multicolumn{2}{|l|}{114} & 0.67 \\
\hline Diskaro & \multicolumn{2}{|l|}{88} & 0.51 \\
\hline Araçapa Makinesi & \multicolumn{2}{|l|}{81} & 0.47 \\
\hline Pülverizatör & \multicolumn{2}{|l|}{58} & 0.34 \\
\hline Gübre Dağıtma Makinesi & \multicolumn{2}{|l|}{57} & 0.33 \\
\hline Tırmık & \multicolumn{2}{|l|}{38} & 0.22 \\
\hline Mibzer (pno) & \multicolumn{2}{|l|}{35} & 0.20 \\
\hline Kültüvatör & \multicolumn{2}{|l|}{31} & 0.18 \\
\hline Sılaj Makinesi & \multicolumn{2}{|l|}{31} & 0.18 \\
\hline Biçme Makinesi & \multicolumn{2}{|l|}{25} & 0.14 \\
\hline Tesviye Makinesi & \multicolumn{2}{|l|}{23} & 0.13 \\
\hline Freze & \multicolumn{2}{|l|}{22} & 0.12 \\
\hline Dip kazan & \multicolumn{2}{|l|}{19} & 0.11 \\
\hline Set Yapma Makinesi & \multicolumn{2}{|l|}{17} & 0.11 \\
\hline Pulluk (dk) & \multicolumn{2}{|l|}{9} & 0.05 \\
\hline Rotatiller & \multicolumn{2}{|l|}{8} & 0.04 \\
\hline Merdane & \multicolumn{2}{|l|}{8} & 0.04 \\
\hline Balya Makinesi & \multicolumn{2}{|l|}{3} & 0.01 \\
\hline Mibzer (mk) & \multicolumn{2}{|l|}{2} & 0.01 \\
\hline Fide Dikim Makinesi & \multicolumn{2}{|l|}{1} & 0.00 \\
\hline \multicolumn{4}{|c|}{ Çizelge 16. Araştırma yöresinin mekanizasyon durumu } \\
\hline Mekanizasyon Düzeyi & İşlenen Alan (ha) & Traktör Sayısı (adet) & Traktör Sayısı (adet/1,000 ha) \\
\hline Araştırmaya katılanlar üreticiler* & 902 & 247 & 273.83 \\
\hline İzmir Yöresi** & $324,152.6$ & 34,811 & 107.39 \\
\hline Türkiye** & $37,817,000$ & $1,332,139$ & 35.22 \\
\hline
\end{tabular}

* Anket yapılan işletmelerin verilerine göre hesaplanmıştır.

** TÜiK, 2018.

Çizelge 17. Araştırma yöresinin işlenen alan başına düşen traktör gücü düzeyi (BG/ha)

\begin{tabular}{|c|c|c|c|c|c|}
\hline Yer & $\begin{array}{l}\text { İşlenen Alan } \\
\text { (ha) }\end{array}$ & $\begin{array}{l}\text { Traktör } \\
\text { Sayısı (adet) }\end{array}$ & $\begin{array}{l}\text { Traktör Gücü } \\
\text { Varlığı (BG) }\end{array}$ & $\begin{array}{l}\text { Mekanizasyon } \\
\text { Düzeyi (BG/ha) }\end{array}$ & $\begin{array}{l}\text { Mekanizasyon Düzeyi } \\
\text { (ha/traktör) }\end{array}$ \\
\hline $\begin{array}{l}\text { Araştırmaya katılanlar } \\
\text { üreticiler* }\end{array}$ & 902 & 247 & 14,760 & 16.36 & 3.65 \\
\hline İzmir Yöresi** & $324,152.6$ & 34,811 & $1,664,361$ & 5,13 & 9.31 \\
\hline Türkiye** & $37,817,000$ & $1,332,139$ & $70,022,656 * * * *$ & 1.85 & 28.38 \\
\hline
\end{tabular}

* Anket yapılan işletmelerin verilerine göre hesaplanmıştır.

** TÜiK, 2018.

**** Türkiye'deki traktör sayısıyla, ortalama traktör gücü 56,32 BG ile çarpılarak hesaplanmıştır (Evcim ve ark., 2005).

BG/ha'dır. Traktör başına ortalama 3.65 ha işlenen alan Traktör başına düşen ekipman sayısı düşmektedir. Yani araştırmaya katılan üreticilerin verilerine göre, bir traktörle ortalama 3.65 ha alan işlenmektedir. İzmir yöresi için 9.31 ha iken, Türkiye genelinde bu değer Yörede araştırmaya katılan üreticilerin mevcut traktör ve mevcut ekipman varlığı ile traktör başına düşen ekipman 28.38 ha/traktör' dür.

varlığı hesaplanmıştır (Çizelge 18).

Çizelge 18. Araştırma yöresinde traktör başına düşen ekipman sayısı

\begin{tabular}{llll}
\hline Yer & Traktör Sayısı (adet) & Ekipman Varlığı (adet) & $\begin{array}{l}\text { Mekanizasyon Düzeyi } \\
\text { (ekipman/traktör) }\end{array}$ \\
\hline Araştırmaya katılanlar üreticiler* & 247 & 808 & 3.27 \\
İzmir Yöresi** & 34,811 & 378,673 & 10,87 \\
Türkiye** & $1,332,139$ & $11,015,998$ & 8.27 \\
\hline
\end{tabular}

* Anket yapılan işletmelerin verilerine göre hesaplanmıştır.

** TÜIK,2018.

Araştırmaya katılan üreticilerin traktör başına 3.2 adet ekipman düşerken, bu durum İzmir yöresi için 10.87 adet ve Türkiye geneli için 8.27 adet olduğu belirlenmiştir.

İşletme başına düşen traktör sayısı

Araştırma yöresinde işletme başına düşen traktör sayısı hesaplanmıştır (Çizelge 19). 
Çizelge 19. Araştırma yöresinde işletme başına düşen traktör sayısı

\begin{tabular}{llll}
\hline Yer & İşletme Sayısı (adet) & Traktör Sayısı (adet) & Traktör Sayısı (adet/işletme) \\
\hline Araştırmaya katılanlar üreticiler* & 170 & 247 & 1.45 \\
İzmir Yöresi** & 72,332 & 34,811 & 0.48 \\
Türkiye** & $3,022,127$ & $1,332,139$ & 0.44 \\
\hline
\end{tabular}

* Anket yapılan işletmelerin verilerine göre hesaplanmıştır.

** Tüik, 2018.

İsletme başına düşen traktör sayısı, araştırmaya katılan üreticiler, İzmir yöresi ve Türkiye geneli için hesaplanmıştır. Sonuca göre yörede araştırmaya kaStılan üreticilerin işletme başına düşen traktör sayısı 1.45 iken, İzmir yöresi için 0.48 ve Türkiye geneli için bu sayı 0.44 olduğu görülmektedir.

\section{SONUÇ}

Sonuç olarak araştırma yöresinden toplanılan verileri değerlendirdiğimizde, çiftçi özellikleri olarak çiftçilik tecrübesinin ortalama 22 yıl olduğu, çiftçi yaş ortalamasının 41 olduğu ve bir yıl içinde çalıştığı gün ortalamasının 299 gün olduğu tespit edilmiştir. Bununla birlikte yöre çiftçisinin $\% 57$ 'sinin ise 1 adet traktöre sahip olduklarını ve yörede kullanılan traktörlerin \%45'inin 1-49 beygir arası güce sahip olduklarını belirtmişlerdir. Yine yörede en yaygın kullanılan traktör markasının Massey Fergusson, Fiat ve New Holland olduğu tespit edilmiştir. Yöre çiftçisinin sahip oldukları mekanizasyon düzeylerine baktığımızda, hemen hemen her çiftçinin bir adet römork'a ve bir adet pulluk'a sahip oldukları tespit edilmiştir. Yörede araştırmaya katılan üreticilerin 1,000 ha işlenen alana düşen traktör sayılarının 273.83 olduğu ve bu sayının İzmir yöresi için 107.39 adet iken, Türkiye geneli sayısının 35.22 olduğu belirlenmiştir. Yörede araştırmaya katılan üreticiler, İzmir yöresi ve Türkiye genelinde işlenen alan başına düşen traktör gücü düzeyi değerlendirildiğinde yöre için bu sonuç yörede araştırmaya katılan üreticiler için $16.36 \mathrm{BG} /$ ha, İzmir yöresi için 5.13 BG/ha iken Türkiye geneli için 1.85 BG/ha olduğu tespit edilmiştir. Bununla birlikte traktör başına işlenen alan miktarı yörede araştırmaya katılan üreticiler için 3.65 ha/traktör, İzmir yöresi için 9.31 ha/traktör iken, Türkiye geneli için 28.38 ha/traktör'dür. Yörede araştırmaya katılan üreticilerin sahip oldukları traktörlerinin başına düşen ekipman sayısı 3.27 ekipman/traktör'dür. Bu sonuç İzmir yöresi için 10.87 ekipman/traktör iken, Türkiye geneli için bu rakam 8.27 ekipman/traktör'dür. Tüm bu verilere ek olarak İzmir yöresindeki ve Türkiye genelindeki işletme başına düşen traktör sayısının İzmir yöresi için 0.48 adet/işletme, Türkiye geneli için 0.44 adet/işletme olduğu belirlenmiştir. Tüm veriler göz önünde bulundurulduğunda yöre çiftçisinin kullandığı traktörlerin markalarının belirli birkaç marka etrafında toplandığı görülmüştür bunun nedeninin ise yöre çiftçisinin kullandığı traktöre olan alışkanlığı olduğu tespit edilmiştir. Yöre çiftçisinin deneyim durumu bize yörede çiftçiliğe yeni başlayanların da mevcut olduğunu göstermektedir. Yörede 56 yaşında ve daha yaşlı olan çiftçilerin hemen hemen tüm yıl çalıştıkları belirlenmiştir.

\section{TEŞEKKÜR}

$\mathrm{Bu}$ çalışma son sınıf lisans bitirme tezi çalışmasıdır. Bu çalışma TÜBiTAK'ın 2209 program kodu ve 1919B011502399 başvuru numarası ile Üniversite Öğrencileri Yurt İçi/Yurt Dışı Araştırma Projeleri Destekleme Programı kapsamında finansal destek almıştır. TÜBITAK'a bu çalışmanın yürütülmesinde vermiş olduğu finansal destekten dolayı teşekkürlerimizi sunarız.

\section{KAYNAKLAR}

Akıncı I, ışık A, Kirişçi V, Say SM (1995) Traktör ve Tarım Makinaları Satın Alma Bedellerinin Değerlendirilmesi. Tarımsal Mekanizasyon 16. Ulusal Kongresi Bildiri Kitabı: 606-617. 5-7 Eylül, Bursa.

Akkaya Ş, Pazarlıŏlu MV (1995) Ekonometri, Anadolu Matbaacılık, 3. Baskı, İzmir.

Başar A, Oktay E (2000) Uygulamalı İstatistik 2, Aktif Yayınevi, 2 Baskı, Erzurum.

Çobanoğlu F, Yılmaz Hi, Tunalıoğlu R, Bozkıran S, Nalbantoğlu A, Yıldız H (2016) Kırsal Kalkınma Yatırımlarını Destekleme Programının Etkisinin Değerlendirilmesi: Sorunlar ve Olası Çözüm Önerileri. Tarımsal Ekonomi ve Politika Geliştirme Enstitüsü(TEPGE), Ankara. http://www.tepge.gov.tr/Dosyalar/Yayinlar/60cb1f74 950e42d5b89064553f0446db.pdf

Doğruak AU (2002) Dünya'da ve Türkiye'de Tarım Traktörleri. Teknik Özellikleri ve Yenilikler. Yüksek Lisans Tezi. Ege Üniversitesi Fen Bilimleri Enstitüsü, İzmir.

Evcim HÜ, Ulusoy E, Gülsoylu E, Sındır K, İçöz E, (2005) Türkiye Tarımı Makineleşme Durumu. Türkiye Ziraat Mühendisleri VI. Teknik Kongresi, Ankara.

Tatlıdil H (1996) Uygulamalı Çok Değişkenli İstatistiksel Analiz. Cem Web Ofset, Ankara.

Tavşancıl E (2002) Tutumların Ölçülmesi ve SPSS ile Veri Analizi. Nobel Yayınevi, Ankara.

TUik, 2018. Türkiye İstatistik Kurumu Ankara. http://www.tuik.gov.tr/VeriBilgi.do?alt_id=1006 